\title{
Matrix Hard - The Impact of Technological, Economic and Social Indicators on Productivity and Competitiveness
}

\author{
${ }^{1}$ Marina POPA, PHD, ${ }^{2}$ Maia PISANIUC, PhD \\ ${ }^{1,2}$ Academy of Economic Studies of Moldova, Republic of Moldova
}

\begin{abstract}
The objective of this research is to demonstrate the impact of technological, economic and social indicators on productivity and competitiveness through the HARD Matrix method, proposed by the European Commission. The level of economic development of different countries, as well as the degree of diversification and specialization of their world production, determines the degree of integration of national economies in the world economy that differs considerably by country and group of countries. The expansion and amplification of the internationalization process have substantially changed the place and role of each state in the world economy. Due to this process, today's world economy is no longer a simple sum of economies put in contact, but a global-universal system, unitary through the interrelationships between the component subsystems and its extremely heterogeneous structure. In the 21 st century, the process of amplifying innovation, the net economy, and the Covid 19 pandemic have shaped new trends in the world countries and determined the balance of power between the three great empires of the world - the United States, the European Union, and China, as long as all three use the levers of globalization to exert its gravitational force. At the same time, there are no similar links between the US, the EU, and China, they do not share the same culture, do not share the same geographical space, and do not use the same models of economic development, but all of them consider innovation, sophisticated business, technology, safe tools in promoting economic growth and competitiveness.
\end{abstract}

Keywords: Matrix HARD, productivity, economic indicator, social indicator, innovation.

\section{Introduction}

The end of the 20th century and the beginning of the 21 st century were marked by a series of events that led to the creation of a new type of socio-economic society, which the New Cambridge School calls the new economy, the informational society, the knowledge society, being influenced by major vectors such as innovational business, internationalization, transnationalisation, and globalization. In this context, the world economy was influenced by a set of changes that have contributed to the design of new trends and features, resulting from the evolution of pre-industrial to post-industrial stages of economic development. According to which world economies have moved towards an innovation-based society, communication, information, and creativity. In the current conditions, terms such as innovative economy, globalization, sophisticated business are not a novelty for the contemporary economy, but they are vital phenomena for the global 


\title{
$11^{\text {th }}$ International Conference on Modern Research in
} MANAGEMENT, ECONOMICS and ACCOUNTING

\author{
18-20 December, 2020 Oxford, United Kingdom
}

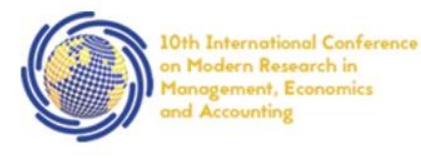

economic process. The wave of globalization from nowadays and implicitly that of internationalization, characterized by net reductions in commercial barriers and the costs of transport, communication, and information, offers various opportunities to national economies. The participation of the states of the world in the world economic system represents the intrinsic condition of the progress and evolution of the civilization of the 21 st century, thus becoming an integral part of an increasingly unitary global economy.

The analysis of the theoretical and methodological scientific approaches regarding the increase of labor productivity in the conditions of internationalization of national economies allows us to formulate the significant scientific problem that was solved. It consists of identifying the factors that contribute to the increase of labor productivity in the national economy, using the HARD Matrix methodology.

In this context, the author aims to make a comparative analysis between three types of indicators: economic, innovative, and social, to determine which has a more precise influence on increasing the productivity and competitiveness of states, which is also the main objective of the research.

The research comprises an introduction, the research methodology, results, conclusions, and bibliography.

\section{Literature review for this study}

In the elaboration of the article, the author researched the specialty literature and the hypotheses of several national authors and international economists such as J. Lahard, R. Solow, L. Voinea, M. Porter. Significant importance in supporting the demonstrated theories had the economic reports of the European Commission, the statistical data provided by EUROSTAT, the World Bank, UNCTAD, and the National Bureau of Statistics.

\section{Methodology}

Following the conducted research on identifying the factors of increasing labor productivity, we developed a model for determining the principal indicators for its increase. Based on this model, we will analyze the level of the Labor Productivity Index both in the Republic of Moldova and in other states. The central objective of the calculation of the Labor Productivity Index is to establish the factors that influence and have a direct impact on it. To carry out this analysis, we used as a benchmark the 'Hard' Matrix, developed within the GOF Project 'Romania-Building Regional Assessment Capacity in Line with the Lisbon Agenda' under the leadership of the Romanian economist Liviu Voinea.

Our model starts from the structural indicators found in international statistics, in particular, we used the categories of indicators proposed by the World Bank, grouped into the following categories: general economic environment, employment, innovation, and research.

Taking into account these elements and the factors that influence labor productivity, we obtain three types of categories, as follows:

- Economic indicators (general economic environment);

- Social indicators (employment);

- Technological indicators (innovation and research). 
$11^{\text {th }}$ International Conference on Modern Research in

MANAGEMENT, ECONOMICS and ACCOUNTING

18-20 December, 2020 Oxford, United Kingdom

Table 1.1

Calculation of the Labor Productivity Index, according to the "Hard" Matrix Method

\begin{tabular}{|c|c|c|c|c|c|}
\hline \multicolumn{2}{|c|}{ Economic Indicator(IE) } & \multicolumn{2}{|c|}{ Social Indicator(IS) } & \multicolumn{2}{|c|}{ TechnologicalIndicator(IT) } \\
\hline Category & Weight & Category & Weight & Category & Weight \\
\hline E1 - GDP/per capita & 30 & $\begin{array}{l}\text { S1 - Degree of } \\
\text { literacy }\end{array}$ & 30 & $\begin{array}{l}\text { T1- Expenses on } \\
\text { research and } \\
\text { development as in } \\
\text { GDP }\end{array}$ & 20 \\
\hline $\begin{array}{l}\text { E2 - GDP growth } \\
\text { rate }\end{array}$ & 10 & $\begin{array}{l}\text { S2 - Total labor } \\
\text { force }\end{array}$ & 40 & $\begin{array}{l}\text { T2- Employed } \\
\text { population with } \\
\text { higher education }\end{array}$ & 30 \\
\hline E3 - Net exports & 30 & $\begin{array}{l}\text { S3 - Employment } \\
\text { - women }\end{array}$ & 10 & $\begin{array}{l}\text { T3-Number of } \\
\text { scientists }\end{array}$ & 20 \\
\hline E4 - FDI inputs & 30 & $\begin{array}{l}\text { S4 - Average life } \\
\text { expectancy index }\end{array}$ & 20 & $\begin{array}{l}\text { T4- Patent } \\
\text { applications } \\
\text { (inhabitants) }\end{array}$ & 30 \\
\hline
\end{tabular}

Source: developed by the author based on

Voinea L. Matricea de evaluare a competitivității regionale: cui folosește și cum se procedează? Manual de evaluare a competitivitătii regionale. Bucharest: GEA, 2007.p. 22-26.

Following the weighting of these three indicators, is established the calculation formula of the Labor Productivity Index (LPI) (the sum of the used weights has a value of 100). Each of these indicators is calculated as a weighted average of the variables selected from each group.

This leads to the following calculation model for the three indicators:

$$
\begin{aligned}
& I_{E}=\frac{30 E 1+10 E 2+30 E 3+30 E 4}{100} \\
& I_{S}=\frac{30 S 1+40 S 2+10 S 3+20 S 4}{100} \\
& I_{T}=\frac{20 T 1+30 T 2+20 T 3+30 T 4}{100}
\end{aligned}
$$

In the end, the value of the Labor Productivity Index, $\mathrm{I}_{\mathrm{LP}}$, is given by the weighted average of the three indicators, economic, social, and technological:

$$
I_{L P}=\frac{40 E I+30 S I+30 T I}{100}
$$

The calculations reflect the contribution of each of the three sub-indicators to the labor productivity indicator. In general, countries with high economic growth, a high degree of innovation, and a high employment rate also tend to have higher labor productivity.

At the same time, in the author's conception, this calculation method makes a much more objective assessment of the level of labor productivity than the relation of GDP does to the labor force. 
$11^{\text {th }}$ International Conference on Modern Research in

MANAGEMENT, ECONOMICS and ACCOUNTING

18-20 December, 2020 Oxford, United Kingdom

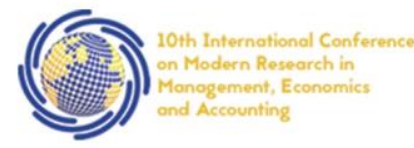

\section{Data analysis and results of research}

The results of the research in some chosen countries

The high level of productivity present in the American economy attracts enormous capital flows but also allows the export of commercial and financial resources all over the world. Economic growth, supported by high-performance technology, intensively promotes the economic concept related to the global productivity of production factors, a phenomenon that emphasizes the effectiveness with which the American economy combines employee work with investment in research and innovation. In the US, increasing labor productivity is experiencing large but short-term fluctuations and some changes marked by economic cycles. Since the post-war period, there was a tendency to increase labor productivity until the recession of 1967 and slower until the early 1980s, with very uneven and very fluctuating recovery delays. From 1995 until now, the "new economy" has generated a dramatic increase in labor productivity.(J.Lahart 2018)

Using the HARD Matrix method, we can easily identify which are the factors with a considerable impact on US economic development. Following the calculations made by the author, it was established that the LPI is 92.32, which explains that the US is a country with increased labor productivity.

Table1.2 Calculation of indicators that influence labor productivity in the USA according to the Hard Matrix method

\begin{tabular}{|c|c|c|c|c|c|}
\hline \multicolumn{2}{|c|}{ Economic Indicator $(E I)$} & \multicolumn{2}{|l|}{ Social Indicator (SI) } & \multicolumn{2}{|c|}{ TechnologicalIndicator $(T I)$} \\
\hline Category & Weight & Category & Weight & Category & Weight \\
\hline $\begin{array}{l}\text { E1 - GDP/per } \\
\text { capita }\end{array}$ & $55836 * 30 \%$ & $\begin{array}{l}\text { S1 - Degree of } \\
\text { literacy }\end{array}$ & $97 * 30 \%$ & $\begin{array}{l}\text { T1- Expenses on } \\
\text { research and } \\
\text { development as \% } \\
\text { of GDP }\end{array}$ & $2,8 * 20 \%$ \\
\hline $\begin{array}{l}\text { E2 - GDP } \\
\text { growth rate }\end{array}$ & $2,9 * 10 \%$ & $\begin{array}{l}\mathbf{S 2}-\text { Total labor } \\
\text { force }\end{array}$ & $\begin{array}{l}165348 * 40 \\
\%\end{array}$ & $\begin{array}{l}\text { T2- Employed } \\
\text { population with } \\
\text { higher education }\end{array}$ & $62832 * 30 \%$ \\
\hline $\begin{array}{l}\text { E3 - Net } \\
\text { exports }\end{array}$ & $2223624 * 30 \%$ & $\begin{array}{l}\mathbf{S 3} \text { - Employment - } \\
\text { women }\end{array}$ & $77166 * 10 \%$ & $\begin{array}{l}\text { T3-Number of } \\
\text { scientists }\end{array}$ & $14567 * 20 \%$ \\
\hline E4-FDI inputs & $378894 * 30 \%$ & $\begin{array}{l}\text { S4- Average life } \\
\text { expectancy index }\end{array}$ & $79 * 20 \%$ & $\begin{array}{l}\text { T4- Triadic patent } \\
\text { families } \\
\text { (inhabitants) }\end{array}$ & $15346 * 30 \%$ \\
\hline Calculated EI & $7978(86 \%)$ & Calculated SI & $729(8 \%)$ & Calculated TI & $525(6 \%)$ \\
\hline
\end{tabular}

Source: author's calculations based on the HARD Matrix model

https://data.worldbank.org/indicator/NY.GDP.PCAP.CD?view=chart

The economic indicator is the factor with the greatest impact on labor productivity, which means that the added value obtained from exports, FDI inputs are the main determinants in its increase. At the same time, the considerable differences between the technological and the economic indicator are reflected by the high weight of the 


\title{
$11^{\text {th }}$ International Conference on Modern Research in
} MANAGEMENT, ECONOMICS and ACCOUNTING

\author{
18-20 December, 2020 Oxford, United Kingdom
}

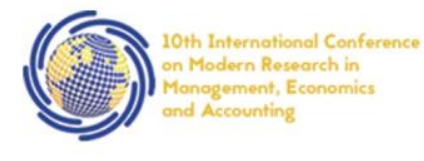

American GDP however, it does not mean that the impact of the social and technological index is lower on the increase of productivity and competitiveness.

Therefore, the high degree of competitiveness and development of the American economy is determined by several aspects: sophisticated business models, the American human potential is among the best in the world, it is the origin country of the most giant, creative and innovative transnational companies in the world; the US dollar is the main international instrument of payment and reserve; English language, which is a vehicle of culture, facilitating the expansion of the American lifestyle to countries with old traditions, endowment with factors and intensive specialization, highly developed domestic competitive environment.

Another country analyzed in our research is Japan. Japan is an important megacenter in the Asian economic space. It is the most advanced country in the world in terms of technological development, and the third country in the world in terms of GDP. Japan is also a major trading force, ranking 4th in world exports. (UNCTAD 2019) It is also a solid financial center, the Tokyo Stock Exchange being one of the most important global financial centers for capitalization and financial transactions.

Calculating the Labor Productivity Index (LPI) in Japan, with the Hard Matrix method, it was established that the LPI is 16.40, which explains that Japan is a country with a lower level of labor productivity compared to the USA.

Table1.3. Calculation of indicators that influence labor productivity in Japan according to the

Hard Matrix method

\begin{tabular}{|c|c|c|c|c|c|}
\hline \multicolumn{2}{|c|}{ Economic Indicator $(E I)$} & \multicolumn{2}{|c|}{ Social Indicator (SI) } & \multicolumn{2}{|c|}{ TechnologicalIndicator $(T I)$} \\
\hline Category & Weight & Category & Weight & Category & Weight \\
\hline $\begin{array}{l}\text { E1 - PIB/per } \\
\text { capita }\end{array}$ & $32227 * 30 \%$ & $\begin{array}{l}\text { S1 - Degree of } \\
\text { literacy }\end{array}$ & $99 * 30 \%$ & $\begin{array}{l}\text { T1- Expenses on } \\
\text { research and } \\
\text { development as } \\
\% \text { of GDP }\end{array}$ & $3,4 * 20 \%$ \\
\hline $\begin{array}{l}\text { E2 - GDP } \\
\text { growth rate }\end{array}$ & $0,47 * 10 \%$ & $\begin{array}{l}\text { S2 - Total labor } \\
\text { force }\end{array}$ & $65348 * 40 \%$ & $\begin{array}{l}\text { T2- Employed } \\
\text { population with } \\
\text { higher education }\end{array}$ & $32832 * 30 \%$ \\
\hline $\begin{array}{lll}\text { E3 - Net } & \text { Nexports }\end{array}$ & $732146 * 30 \%$ & $\begin{array}{l}\text { S3- } \\
\text { Employment - } \\
\text { women }\end{array}$ & $27166 * 10 \%$ & $\begin{array}{l}\text { T3-Number of } \\
\text { scientists }\end{array}$ & $926671 * 20 \%$ \\
\hline E4 - FDI inputs & $-2250 * 30 \%$ & $\begin{array}{l}\text { S4 - Average } \\
\text { life expectancy } \\
\text { index }\end{array}$ & $89 * 20 \%$ & $\begin{array}{l}\text { T4- Triadic } \\
\text { patent families } \\
\text { (inhabitants) }\end{array}$ & $16946 * 30 \%$ \\
\hline Calculated EI & $2299(50 \%)$ & Calculated SI & $289(6 \%)$ & Calculated TI & $2002(44 \%)$ \\
\hline
\end{tabular}

Source: author's calculations based on the HARD Matrix model

https://data.worldbank.org/indicator/NY.GDP.PCAP.CD?view=chart

The economic indicator is practically equal to the technological one as a weight, but as an impact, innovation determines the increase of labor productivity the most. The extremely low weight of the social index demonstrates the severe demographic problems and the lack of labor force that Japan faces today. 


\section{$11^{\text {th }}$ International Conference on Modern Research in}

\section{MANAGEMENT, ECONOMICS and ACCOUNTING}

\section{8-20 December, 2020 Oxford, United Kingdom}

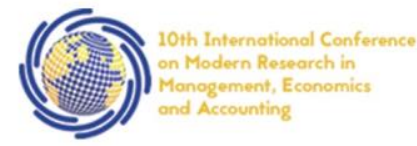

To increase the level of labor productivity and reset the entire economy, Japan must quickly take several measures:

- Slowing the tendency of decrease in the labor force by increasing the employment rate of women, thus reducing inequalities between the active female and male labor force. Another measure would be to increase the employment of foreign workers;

- Improving the business environment by successfully using advanced innovative business models to stimulate increased labor productivity by promoting flexibility and mobility in the labor market, establishing a more favorable climate for foreign entrepreneurs, boosting capital inflows to facilitate entrepreneurship and innovation;

- Reduction of public debt.

The Labor Productivity Index of the European Union, calculated with the Hard Matrix method, is 59.1, which is the European average. The author calculated the LPI for the European Union as a whole of 27 states. It is worth mentioning that the indicator may be different if we calculate each EU country separately. Table 1.3 describes the analyzes and calculations of the European average index.

Table 1.4. Calculation of indicators that influence labor productivity in the European Union according to the Hard Matrix method

\begin{tabular}{|c|c|c|c|c|c|}
\hline \multicolumn{2}{|c|}{ Economic Indicator $(E I)$} & \multicolumn{2}{|l|}{ Social Indicator (SI) } & \multicolumn{2}{|c|}{ TechnologicalIndicator (TI) } \\
\hline Category & Weight & Category & Weight & Category & Weight \\
\hline $\begin{array}{l}\text { E1 - PIB/per } \\
\text { capita }\end{array}$ & $31668 * 30 \%$ & $\begin{array}{l}\text { S1 - Degree of } \\
\text { literacy }\end{array}$ & $95 * 30 \%$ & $\begin{array}{l}\text { T1- Expenses } \\
\text { on research and } \\
\text { development as } \\
\% \text { of GDP }\end{array}$ & $2,03 * 20 \%$ \\
\hline $\begin{array}{l}\text { E2 }- \text { GDP } \\
\text { growth rate }\end{array}$ & $1,96 * 10 \%$ & $\begin{array}{l}\text { S2 - Total labor } \\
\text { force }\end{array}$ & $\begin{array}{l}248347 * \\
40 \%\end{array}$ & $\begin{array}{l}\text { T2- Employed } \\
\text { population with } \\
\text { higher education }\end{array}$ & $149008 * 30 \%$ \\
\hline E3 - Net exports & $\begin{array}{l}7115901 * 30 \\
\%\end{array}$ & $\begin{array}{l}\text { S3 - Employment - } \\
\text { women }\end{array}$ & $\begin{array}{l}112259 * \\
10 \%\end{array}$ & $\begin{array}{l}\text { T3-Number of } \\
\text { scientists }\end{array}$ & $2801321 * 20 \%$ \\
\hline E4 - FDI inputs & $439458 * 30 \%$ & $\begin{array}{l}\text { S4 - Average life } \\
\text { expectancy index }\end{array}$ & $81 * 20 \%$ & $\begin{array}{l}\text { T4- Triadic } \\
\text { patent families } \\
\text { (inhabitants) }\end{array}$ & $14568 * 30 \%$ \\
\hline Calculated EI & $9104(55,84)$ & Calculated SI & $\begin{array}{l}1105 \\
(6,78 \%)\end{array}$ & Calculated TI & $6093(37,37 \%)$ \\
\hline
\end{tabular}

Labor Productivity Index, European Union = 59,1

Source: developed by the author based on the Hard Matrix model, proposed in the Lisbon Agenda of the EU https://data.worldbank.org/indicator/NY.GDP.PCAP.CD?view $=$ chart

The economic indicator and the technological indicator are the main determinants of labor productivity, which means that the benefit obtained from exports, FDI inputs are the main factors in its increase. As in the case of the correlation method, it is observed that investments in research, development, intelligent human factor, education, patents are factors that directly influence the increase of labor productivity in the European 


\title{
$11^{\text {th }}$ International Conference on Modern Research in
}

\section{MANAGEMENT, ECONOMICS and ACCOUNTING}

\author{
18-20 December, 2020 Oxford, United Kingdom
}

Union. On the other hand, the social index has a very low weight, which confirms serious unemployment problems, the refugee crisis, and the lack of jobs.

Using the Hard Matrix method in the case of the Republic of Moldova, it proved that the Economic Indicator is the one that has a more powerful impact than the social and technological indicator. Such a considerable gap between indicators (Economic Indicator 57\%, Social Indicator 27\%, Technological Indicator 15\%) confirms the results obtained previously regarding the importance of specific factors in increasing labor productivity in the national economy. The Republic of Moldova is a country at the stage of development based on primary factors, and the technological and innovative concept is just at the beginning moreover, their influence on increasing labor productivity is determined by only $15 \%$.

Table 1.5. Calculation of indicators that influence labor productivity in the Republic of Moldova according to the Hard Matrix method

\begin{tabular}{|c|c|c|c|c|c|}
\hline \multicolumn{2}{|c|}{ Economic Indicator (EI) } & \multicolumn{2}{|c|}{ Social Indicator (SI) } & \multicolumn{2}{|c|}{ TechnologicalIndicator (TI) } \\
\hline Category & Weight & Category & Weight & Category & Weight \\
\hline $\begin{array}{l}\text { E1 - PIB/per } \\
\text { capita }\end{array}$ & $1589 * 30 \%$ & $\begin{array}{l}\text { S1 - Degree of } \\
\text { literacy }\end{array}$ & $98 * 30 \%$ & $\begin{array}{l}\text { T1- Expenses on } \\
\text { research and } \\
\text { development as } \\
\% \text { of GDP }\end{array}$ & $2,5 * 20 \%$ \\
\hline $\begin{array}{l}\text { E2 - GDP } \\
\text { growth rate }\end{array}$ & $-0,5 * 10 \%$ & $\begin{array}{l}\text { S2 - Total labor } \\
\text { force }\end{array}$ & $1255 * 40 \%$ & $\begin{array}{l}\text { T2- Employed } \\
\text { population with } \\
\text { higher education }\end{array}$ & $485 * 30 \%$ \\
\hline $\begin{array}{l}\text { E3 - Net } \\
\text { Exports }\end{array}$ & $2482 * 30 \%$ & $\begin{array}{l}\text { S3- Employment - } \\
\text { women }\end{array}$ & $620 * 10 \%$ & $\begin{array}{l}\text { T3-Number of } \\
\text { scientists }\end{array}$ & $1750 * 20 \%$ \\
\hline $\begin{array}{l}\text { E4 - FDI } \\
\text { inputs }\end{array}$ & $228 * 30 \%$ & $\begin{array}{l}\text { S4 - Average life } \\
\text { expectancy index }\end{array}$ & $71 * 20 \%$ & $\begin{array}{lr}\text { T4- } & \text { Triadic } \\
\text { patent families } \\
\text { (inhabitants) }\end{array}$ & $64 * 30 \%$ \\
\hline Calculated EI & $\begin{array}{c}12.83 \\
(57,12 \%)\end{array}$ & Calculated SI & $\begin{array}{c}6.14 \\
(27,33 \%)\end{array}$ & Calculated TI & $\begin{array}{c}3.49 \\
(15,55 \%)\end{array}$ \\
\hline
\end{tabular}

Source: developed by the author based on theHard Matrix model,proposed in the Lisbon Agenda of the EU, using data provided by UNCTAD, the World Bank, and the National Bureau of Statistics, www.statistica.md

Making a comparative analysis between the Republic of Moldova and the states analyzed above, we perceive that the gaps are tremendous.

At the same time, we see gaps in indicators at the national level. The Republic of Moldova is divided into three principal regions: the Northern Development Region (NDR), the Southern Development Region (SDR), and the Central Development Region (CDR). By calculating the Productivity Index for each region individually, we can determine which of them is more attractive for investment and promotion of innovational business.

That is a new approach for the Republic of Moldova about identifying the factors of increasing labor productivity by calculating the Labor Productivity Index (LPI) with the Hard Matrix method for each region of economic development in the country. Following the calculations of LPI, a curious aspect emerges. The LPI in Chisinau is 0.101, which is a higher indicator than the national one. That result confirms the idea stated 
$11^{\text {th }}$ International Conference on Modern Research in

MANAGEMENT, ECONOMICS and ACCOUNTING

\section{8-20 December, 2020 Oxford, United Kingdom}

above regarding the major discrepancies between the level of development registered in Chisinau in contrast to the rest regions of the country.

Table 1. 6 Calculation of indicators that influence labor productivity in the developing regions of the Republic of Moldova according to the Hard Matrix method

\begin{tabular}{|l|c|l|c|l|c|c|}
\hline \multicolumn{2}{|c|}{ Economic Indicator (EI) } & \multicolumn{2}{c|}{ Social Indicator (SI) } & \multicolumn{2}{c|}{ TechnologicalIndicator } & LPI \\
\hline \multicolumn{1}{|c|}{ Region } & Weight & Region & Weight & \multicolumn{1}{c|}{ Region } & Weight & \\
\hline NDR & $\begin{array}{c}9,53 \\
(72 \%)\end{array}$ & NDR & $\begin{array}{c}2,21 \\
(16,70 \%)\end{array}$ & NDR & $\begin{array}{c}1,52 \\
(11,29 \%)\end{array}$ & $\mathbf{0 , 0 6 3}$ \\
\hline CDR & $\begin{array}{c}3,95 \\
(59,39 \%)\end{array}$ & CDR & $\begin{array}{c}1,80 \\
(27,06 \%)\end{array}$ & CDR & $\begin{array}{c}0,90 \\
(13,55 \%)\end{array}$ & $\mathbf{0 , 0 5 1}$ \\
\hline SDR & $\begin{array}{c}5,01 \\
(75,67 \%)\end{array}$ & SDR & $\begin{array}{c}1,11 \\
(16,76 \%)\end{array}$ & SDR & $\begin{array}{c}0,50 \\
(7,57 \%)\end{array}$ & $\mathbf{0 , 0 4 5}$ \\
\hline Chișinău & $\begin{array}{c}24,83 \\
(80,20 \%)\end{array}$ & Chișinău & $\begin{array}{c}3,12 \\
(10,07 \%)\end{array}$ & Chișinău & 3,01 & $\mathbf{0 , 1 5 1}$ \\
\hline \multicolumn{7}{|c|}{ Labor ProductivityIndex, the Republic of Moldova = 0,099 } \\
\hline
\end{tabular}

Source: developed by the author based on the Hard Matrix model, proposedin the Lisbon Agenda of the EU, using data provided by the National Bureau of Statistics, www.statistica.md

Using this method in the case of developing regions in the Republic of Moldova, it was established that the Economic Indicator is the one that has a much higher net impact than the social and technological indicator. Such a large gap between indicators demonstrates the same characteristic hypothesis for the entire economy, namely, the fact that regions are poorly developed economically, based on primary factors, and the technological and innovation concept is underdeveloped, thus the transition from Factor Driven to Efficiency Driven is about the future.

\section{Conclusions}

Following the calculations made by the author, based on the Hard Matrix Method, it was established that the LPI in the USA is 92.32, in Japan is 16.40, and in the European Union 27, it is 59.1, which explains that there are countries with increased labor productivity. In the US, the economic indicator is the factor with the greatest impact on labor productivity. In Japan, the economic indicator is practically equal to the technological one in terms of weight, but as an impact, innovation determines the increase of labor productivity the most. In European Union countries, the economic indicator and the technological indicator are the main determinants of labor productivity.

Using the method Hard Matrix to determine the factors of increasing labor productivity in the Republic of Moldova, including in its developing regions, it was established that the Economic Indicator is the one that has a net impact higher than the 


\section{$11^{\text {th }}$ International Conference on Modern Research in}

social and technological indicator. Such a large gap between them demonstrates the same characteristic hypothesis for the entire economy, specifically, the fact that regions are poorly developed economically, based on primary factors, and the technological and innovation concept is underdeveloped, moreover the transition from Factor Driven to Efficiency Driven is about the future. There is a substantial difference between Productivity Indices calculated between regions and Chisinau.

For the Republic of Moldova, the author identifies the factors for increasing labor productivity by calculating the Labor Productivity Index (LPI) by the Hard Matrix method and for each region of economic development in the country. Following the calculations of the LPI, an interesting aspect is outlined. The LPI in Chisinau is 0.101, which is a higher indicator than the national one. This result confirms the major discrepancies between the level of development registered in Chisinau compared to the rest of the regions in the country.

\section{References}

Competitiveness at a glance. In: Industry Monitor. 2016. www.industry.gov.au/oce

Drzeniek-Hanouz M. Global finances set to brighten - and other top economic stories of the

week. World Economic Forum, Geneva, 2017.

https://www.weforum.org/agenda/2017/06/global-gdp-rise-top-economicsstories-of week/

Economy Rankings. World Bank 2016. http://www.doingbusiness.org/rankings

Eichengreen B., Park D., Shin K. The Global Productivity Slump: Common and CountrySpecific

Factors NBER Cambridge: Working Paper 21556, 2015, no. 21556. 54 p. Issued in September NBER Program(s): IFM

European Commission. Innovation Union - Europe 2020 iniative.

http://ec.europa.eu/research/innovation-union/index_en.cfm?pg=eip

Gotişan Ș. Impactul politicilor economice din Republica Moldova în perspectiva de integrare

europeană. Chişinău, 2011. 56 p.

Gotişan I. Disparităţi economice regionale în Republica Moldova. În: IDIS, 2016, nr. 11, p. 1-26.

Hotărîre cu privire la aprobarea Strategiei Inovaţionale a Republicii Moldova pentru perioada 2013-2020 „Inovaţii pentru competitivitate”.Nr. 952 din 27 noiembrie 2013. In: Monitorul Oficial al Republicii Moldova 06.12.2013, nr. 284289.

Popa M. L'innovation des États-Unis et l'Union Européenne dans les conditions de compétition 
$11^{\text {th }}$ International Conference on Modern Research in MANAGEMENT, ECONOMICS and ACCOUNTING

\section{8-20 December, 2020 Oxford, United Kingdom}

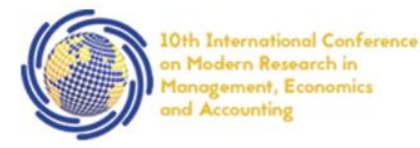

mondiale. În: Studii Europene, 2015, nr. 6, p. 148-165. ISSN 2345-1041. http://studiieu.org/files/publications/SE\%20N6.pdf

Popa M. Necesitatea elaborării unei politici industriale inteligente în Republica Moldova. In:

Conferinţa ştiinţifică internaţională "Republica Moldova: 20 de ani de reforme economice", (23-24 sept. 2011). Chişinău: ASEM, 2011, vol. 1, p. 403-407.

Popa M. Economia Republicii Moldova la 25 de ani de independenţă. Perpetuarea sa în etapa

de dezvoltare economică Factor Driven. Studii Europene. Chişinău, 2017, Nr.9.2 p.75-99. 0,87 c.a, ISSN 2345-1041 ISSN-L 2345-1041, Indexare Gesis-SSOAR http://studiieu.org/files/publications/SE-9-2017-47758.pdf. (vizitat 27.10.2017).

Voinea L. Matricea de evaluare a competitivităţii regionale: cui foloseşte şi cum se procedează? Manual de evaluare a competitivităţii regionale. Bucuresti: GEA, 2007.p. 22-26.

Voinea L. Reindustrializarea României: Politici și strategii. Studiu realizat de Grupul de Economie Aplicată - GEA. București: GEA, 2010. 172 p.

*This article is the result of studies conducted in the National Research Project No. 20.80009.1606.42: Configurarea businessului inovațional în contextul concurenței regionale. 